\title{
ANALISIS PROFITABILITAS BANK UMUM GO PUBLIC PADA BURSA EFEK INDONESIA (BEI)
}

\author{
Akhmad Reza Liannoor \\ Alamat afiliasi
}

\begin{abstract}
The rapid development of the banking world today is to encourage banks to improve their performance in competition between banks for customers. One tool for assessing bank performance is Return on Assets ratio (ROA). The purpose of this study is to analyze the effect of CAR, NPL, LDR, BOPO to ROA on the banks go public in Indonesia Stock Exchange the period 2007-2011. Based on the results of hypothesis tests conducted it was found that the $\mathrm{F}$ test showed independent variable CAR ratio, NPL, LDR, ROA, simultaneous or simultaneously effect of the variable ROA, can be seen from the calculated value of the $\mathrm{F}$ test 191.77> F-table 2.467. To test $\mathrm{T}$ concluded that the variables NPL and bopo significant negative effect so it can dikatankan ROA hypothesis that negatively affect profitability (ROA) is acceptable, while the variable CAR is not negative and not positive LDR variable, so the hypothesis that the CAR positive effect on profitability (ROA) is unacceptable as well as variables which hypothesis holds LDR LDR positive effect on profitability (ROA) is not acceptable. While the test of determination $\mathrm{R} 2$, Independent variables influence the dependent variable is large enough, judging from the value of the coefficient $\mathrm{R} 2$ is equal to $68.9522 \% 31.0478 \%$ while the remaining approximately explained by other variables that are not included in this research model.
\end{abstract}

Keywords : Performance, Return on Assets, Capital Adequacy Ratio, Non Performing Loan, Loan to Deposit Ratio and Operational costs to Operating Income

\begin{abstract}
ABSTRAK
Pesatnya perkembangan dunia perbankan dewasa ini mendorong bankbank dalam meningkatkan kinerjanya dalam persaingan antar bank untuk mendapatkan nasabah. Salah satu alat untuk menilai kinerja perbankan adalah dengan rasio Return On Asset (ROA). Adapun tujuan dari penelitian ini yaitu untuk menganalisis pengaruh CAR, NPL, LDR, BOPO terhadap ROA pada bank umum Go Public di Bursa Efek Indonesia periode 2007-2011.Berdasarkan hasil uji hipotesis dilakukan didapatkan bahwa uji $\mathrm{F}$ menunjukkan variabel bebas Rasio CAR, NPL, LDR, BOPO, berpengaruh simultan atau serentak terhadap variabel ROA, dapat dilihat dari nilai uji F-hitung 191,77> F-tabel 2,467. Untuk uji T disimpulkan bahwa variabel NPL dan BOPO berpengaruh negatif signifikan terhadap ROA sehingga dapat dikatankan hipotesis yang menyatakan berpengaruh negatif terhadap profitabilitas (ROA) dapat diterima, sementara itu variabel CAR tidak berpengaruh negatif dan variabel LDR tidak berpengaruh positif, sehingga hipotesis yang menyatakan bahwa CAR berpengaruh positif terhadap profitabilitas (ROA) tidak dapat diterima sama halnya dengan variabel LDR dimana hipotesis menyatakan LDR berpengaruh positif terhadap profitabilitas (ROA) tidak dapat diterima. Sedangkan Uji Determinasi $\mathrm{R}^{2}$, pengaruh variabel
\end{abstract}


Independent terhadap variabel Dependent adalah cukup besar, dilihat dari nilai koefisien $\mathrm{R}^{2}$ yaitu sebesar 68,9522\% sedangkan sisanya sekitar 31,0478\% dijelaskan oleh variabel-variabel lain yang tidak termasuk dalam model penelitian ini.

Kata Kunci : Kinerja, Return On Asset, Capital Adequacy Ratio, Non Performing Loan, Loan to Deposit Ratio dan Biaya Operasiona terhadap Pendapatan Operasional

\section{PENDAHULUAN}

Perekonomian indonesia pada tahun 1997 sampai dengan 1998 mengalami krisis moneter yang berkepanjangan selama setahun, salah satu penyebab krisis tersebut lemahnya kurs nilai tukar rupiah terhadap nilai tukar dollar AS. Dampak yang sangat terlihat banyak nya perusahaan yang tidak aktif dalam usaha bisnis hanya perusahaan besar saja yang tetap menjalankan bisnisnya itupun perusahaan melakukan PHK besarbesaran dengan alasan perusahaan tidak mampu memberikan upah kepada para pekerja, dari pemutus hubungan kerja tersebut tentunya akan menambah jumlah angka penggaruan dan secara tidak langsung krisis moneter juga mempengaruhi kinerja perbankan di Indonesia melemahnya sistem keamanan perbankan di Indonesia, dari lemahnya sistem keamanan pada perbankan tersebut, permasalahn hutang swasta eksternal langsung beralih menjadi masalah perbankan dalam negeri, menyebabkan banyak bank-bank yang mengalami kesulitan keuangan sehingga menyebabkan bangkrutnya usaha tersebut.

Dalam mengatasi permasalahan tersebut pemerintah mengambil kebijakan untuk melikudasi bank sakit akan tetapi strategi yang dilakukan pemerintah untuk mengatasi permasalah tersebut membuat masyarakat bertambah panik yang memperparah efek krisis yakni timbulnya ketidak percayaan masyarakat pada lembaga perbankan atau krisis kepercayaan. Untuk mengembalikan krisis kepercayaan tersebut, sekali lagi pemerintah berkerja sama dengan Bank Indonesia mengeluarkan empat kebijakan untuk mengatasi permasalahan tersebut antara lain yang pertama pemberian bantuan likuiditas bank Indonesia, kedua program penjaminan pemerintah, 
ketiga pendirian badan penyehatan perbakan (BPPN), dan yang ke empat restrukrisasi perbankan.

Setelah melakukan restrukturisasi perbankan, pada tahun $1999 \quad$ sampai 2007 perbankan Indonesia mulai bangkit kembali sepanjang tahun 20072011 terdapat 31 bank yang tercatat sebagai emiten yang mana menjual sahamnya kepublic. Dari perkembangan jumlah bank yang semakin pesat mendorong meningkatnya persaingan antara bank yang satu dengan bank yang lainnya dalam menghimpun dana dari masyarakat. Dengan meningkatnya persaingan antar bank, maka secara tidak langsung menuntut manajemen bank memperbaiki atau meningkatkan kinerjanya. Dengan kata lain jika suatu bank memiliki kinerja yang baik tentunya masyarakat akan menanamkan dananya pada bank tersebut, dalam hal menunjukkan adanya kepercayaan masyarakat bahwa bank tersebut dapat memenuhi harapanya (Ponttie:2007).

Dalam melakukan penilaian kinerja pihak bank dapat melakukan analisis laporan keuangannya, Dari hasil laporan keuangan tersebut investor dapat menilai kinerja dari manajemen bank tersebut. Kinerja peusahaan lazimnya dapat diukur dengan mengetahui bagaimana kemampuan suatu perusahaan dalam menghasilkan laba. Salah satu indikator yang dapat menggukur kemampuan kinerja suatu perusahaan menghasilkan adalah dengan menggunakan analisis profitabilitas. Menurut Sartono (2001) menyatakan bahwa profitabilitas adalah kemampuan perusahaan memperoleh laba dalam hubungannya dengan penjualan total aktiva maupun model sendiri. Terdapat dua alat analisis dalam ratio profitabilitas pertama rasio Return On Assets (ROA) dan yang kedua Return On Equty (ROE), akan tetapi disini peneliti hanyaa menggunakan rasio ROA saja dikarenakan selain merupakan ukuran profitabilitas bank rasio ini sekaligus merupakan indikator efesiensi manajerial bank yang mengindikasikan kemampuan manajeman dalam mengelola asetnya untuk memperoleh 
keuntungan (Mudrajad Kuncoro : 2002).

Semakin besar ROA menunjukkan kinerja keuangan yang semakin baik karena tingkat kembali semakin besar, dengan kata lain jika ROA meningkat berarti profitabilitas perusahaan meningkat, sehingga dampak yang nanti akan meningkatkan profitabilitas yang dinikmati oleh pemegang saham (Husnan 1998). Adapun indikator indikator yang berkaitan dengan analisis ROA ini seperti Capital Adequacy Ratio (CAR) mewakili faktor resiko, Ratio Loan to Deposito Ratio (LDR) untuk mewakili ukuran likuiditas bank, Non Perfoming Loan (NPL) untuk mengukur kemampuan manajemen bank dalam mengelola kredit bermasalah, Biaya Operasional dan Pendapatan Operasional (BOPO) untuk mengukur tingkat kemampuan pendapatan operasional dalam menutup biaya operasional.

Berdasarkan penelitian Muhammad Shobirin (2009) analisis faktor-faktor yang mempengaruhi profitabilitas industri perbankan syariah", menyimpulkan bahwa empat variabel yang sudah dipaparkan diatas menunjukkan bahwa variabel NPL berpengaruh negatif signifikan terhadap ROA. Dengan demikian hipotesis yang menyatakan NPL berpengaruh negatif terhadap ROA dapat diterima. Sedangkan untuk variabel CAR, dan LDR/FDR berpengaruh positif signifikan terhadap ROA, sementara itu hasil analisis Ayu Intan bertentangan dengan analisis M.Shobirin, dimana Ayu Intan menyatakan bahwa variabel CAR berpengaruh negatif terhadap ROA, untuk itu peneliti tertarik menguji kembali variabel CAR.

Berdasarkan permasalahan yang ada diatas dan penelitian yang dilakukan sebelumnya, melihat besarnya porsi rasio ROA terhadap kinerja bank umum Go Public maka peneliti tertarik meneliti dan mengambil judul Analisis Profitabilitas Bank Umum yang Go Publik pada Bursa Efek Indonesia (BEI).

\section{METODE PENELITIAN}


Jenis penelitian berupa studi kasus, yaitu permasalahan yang ditentukan dalam penelitian merupakan masalah yang terjadi pada sample penelitian itu sendiri yaitu bank-bank yang Go Public di BEI sebanyak 20 bank, dan pemecahannya juga dilakukan oleh perusahaan obyek penelitian yang bersangkutan.

Jenis data yang digunakan dalam penelitian ini adalah data sekunder, yaitu data kuantitatif berupa laporan keuangan bankbank yang Go Public di Bursa Efek Indonesia (BEI) selama 5 tahun berturut-turut dari periode 2007 sampai 2011. Data tersebut diperoleh dari beberapa sumber diantaranya melalui media perantara yaitu www.bei.co.id, Indonesia Capital Market Directory (ICMD) 2011.

Teknik yang digunakan adalah metode dokumentasi yaitu dengan cara mengumpulkan, mencatat dan memfotocopy dari arsip maupun dokumentasi perusahaan yang relevan.

Teknik sample yang digunakan dalam penelitian ini adalah dengan Metode Purposive
Sampling, merupakan teknik non probability sampling, dimana peneliti telah membuat batasanbatasan berdasarkan kriteria subyek yang akan dijadikan sampel penelitian. Dari penjelasan tersebut peneliti memberikan kriteria sampel penelitian sebagai berikut :

a. Terdaftar pada Bursa Efek Indonesia selama tahun 2007-2011.

b. Menerbitkan laporan keuangan lima tahun berturut-turut selama tahun 2007-2011.

c. Mempunyai laporan keuangan paling lengkap dan telah dipublikasikan di Bursa Efek Indonesia (BEI) Variabel-variabel yang diamati dalam penelitian ini adalah sebagai berikut:

a. Return On Asset (ROA), mengukur kemampuan perusahaan menghasilkan laba dengan menggunakan total aset (kekayaan) yang dipunyai perusahaan setelah disesuaikan dengan biaya biaya untuk mendanai aset 
tersebut (M Mamduh dan

Abdul Halim 2003).

$$
\begin{gathered}
\text { ROA }=\frac{\text { Laba Bersin Sebelum Pajak }}{\text { Total } \text { Aset }} \mathrm{X} \\
100 \%
\end{gathered}
$$

b. Capital Adequacy Ratio (CAR), rasio yang memperlihatkan seberapa jauh seluruh aktiva bank yang mengandung risiko (kredit, penyertaan, surat berharga, tagihan pada bank lain) ikut dibiayai dari dana modal sendiri bank disamping memperoleh dana-dana dari sumber-sumber dari luar bank, seperti dana dari masyarakat, pinjaman dan lainlain.

$$
C A R=\frac{\text { Modal Sendiri }}{A T M R} \times 100 \%
$$

c. Non Performing Loan (NPL), merupakan penilaian terhadap kondisi bank dan kecukupan manajemen risiko kredit. Peraturan BI Nomor 6/10/PBI/2004 tanggal 12 April 2004 tentang sistem penilaian tingkat kesehatan Bank umum, semakin tinggi nilai NPL (diatas 5\%) maka bank tersebut tidak sehat, NPL yang tinggi menyebabkan menururnya laba yang akan diterima oleh bank.

$$
N P L=\frac{\text { Kredit Bermasalah }}{\text { Total Kredit }} \times 100 \%
$$

d. Loan to Deposito Ratio (LDR), Rasio ini menggambarkan kemampuan bank membayar kembali penarikan yang dilakukan nasabah deposan dengan mengandalkan kredit yang diberikan sebagai sumber likuiditasnya. Semakin tinggi rasio ini semakin rendah pula kemampuan likuiditas bank (Dendawijaya, 2000). $N P L=\frac{J m l h \text { Krdt } Y g \text { dibriakn }}{\text { Total DPK }} \times 100 \%$

e. Biaya operasi dan pendapatan operasi (BOPO), mengukur tingkat efisiensi dan kemampuan bank dalam melakukan kegiatan operasinya.

$$
\text { BOPO }=\frac{\text { Biaya Operasional }}{\text { Pend.Operasional }} \times 100 \%
$$

\section{Metode Analisis Data}

Metode regresi data panel adalah data yang diperoleh dengan menggabungkan antara data berkala (Time Seris) dan data silang (Cross Section). Data Cross Section dalam penelitian ini adalah data 20 perbankan yang go publik, sedangkan data time series dalam penelitian ini adalah data tahun 
2007 sampai dengan tahun 2011.

Dengan mengkombinasikan data berkala (Time Seris) dan data tampang lintang (Cross Section) memberikan data yang lebih informatif, lebih variatif, kurang korelasi antarvaribelnya, lebih banyak derajat kebebasannya dan lebih efisien.

Ada beberapa metode untuk melakukan estimasi parameter regresi data panel, seperti melakukan pendekatan Common Effect, Fixed Effect, dan Random Effect.

Berikut metode Regresi data panel yang digunakan :

$Y_{i t}=\beta_{0}+\beta_{1} X_{i t}+\beta_{2} X_{i t}+\beta_{3} X_{i t}+\beta_{4} X_{i t}$

$$
+\mathrm{e}_{\mathrm{it}}
$$

Keterangan :

$\mathrm{Y}_{\mathrm{it}} \quad=$ Profitabilitas $(\mathrm{ROA})$

a $=$ Konstanta/intercep

$\beta_{1} \ldots \beta_{5}=$ Koefisien regresi dari setiap variabel independen

$\mathrm{X}_{1}=$ Capital Adequacy Ration

$\mathrm{X}_{2} \quad=$ Non Performing Loan

$\mathrm{X}_{3} \quad=$ Loan To Deposit Ratio

$\mathrm{X}_{4} \quad=$ Biaya Operasional terhadap

Pendapatan Operasional

$\mathrm{e}_{\mathrm{it}} \quad=$ Variabel penggangu (error).

\section{Deskripsi Objek Penelitian}

Obyek yang digunakan dalam penelitian ini adalah bank umum go publik pada Bursa Efek Indonesia (BEI) periode tahun 2007 sampai 2011. Selama periode lima tahun tersebut terdapat 31 Bank umum yang tercatat dalam Bursa Efek Indonesia (BEI). Adapun metode yang digunakan dalam penelitian ini adalah purposive sampling dimana peneliti memberikan karakteristik terhadap sample. Berdasarkan kriteria yang dipaparkan maka terdapat 20 Bank aktif dalam pelaporan laporan keuangan.

\section{Analisis Regresi Data Panel}

Berikut hasil dari regresi data panel dengan teknik Common Effect (metode Least Squares)

\section{a. Common Effect}

Dari hasil regresi Common Effect (metode Least Squares) maka didapatkan persamaan sebagai berikut :

$$
\begin{aligned}
& \text { Yit }=\beta \text { o }+\beta 1 \text { Xit }+\beta 2 \text { Xit }+ \\
& \beta 3 \text { Xit }+\beta 4 \text { Xit }+ \text { eit } \\
& \text { Yit }=8,816026-0,008127 X 1 \\
& -0,0171917 X 2+0,008062 X 3 \\
& -0,083289 X 4
\end{aligned}
$$

\section{PEMBAHASAN}


Dari persamaan metode Common Effect di atas, maka dapat diartikan sebagai berikut :

$\mathrm{Y}=$ Variabel terikat yang nilainya akan diprediksi oleh variabel bebas. Dalam penelitian ini yang menjadi variabel terikat adalah tingkat profitabilitas (ROA) yang nilainya diprediksi oleh Capital Adequacy Ration (CAR), Non Performing Loan (NPL), Loan to Deposit Ratio (LDR) dan Biaya Operasional terhadap Pendapatan Operasional (BOPO).

$\mathrm{a}=8.816026$ merupakan nilai konstanta, yaitu estimasi dari tingkat profitabilitas (ROA, jika variabel bebas yang terdiri dari variabel Capital Adequacy Ration (CAR), Non Performing Loan (NPL), Loan to Deposit Ratio (LDR) dan Biaya Operasional terhadap Pendapatan Operasional (BOPO) mempunyai nilai sama dengan nol, maka tingkat profitabilitas (ROA) yaitu sebesar 8.816026 . $\beta 1=\quad-0.008127 \quad$ merupakan besarnya kontribusi variabel Capital Adequacy Ration (CAR) yang mempengaruhi tingkat profitabilitas (ROA). Koefisien regresi (b1) sebesar 0.008127 dengan tanda negatif. Jika variabel Capital Adequacy Ration (CAR) tumbuh 1\% maka tingkat profitabilitas (ROA) akan turun sebesar $0.8127 \%$.

$\beta 2=\quad-0.171917$ merupakan besarnya kontribusi variabel Non Performing Loan (NPL) yang mempengaruhi tingkat profitabilitas (ROA). Koefisien regresi (b2) sebesar 0.171917 dengan tanda negatif. Jika variabel Non Performing Loan (NPL) tumbuh $1 \%$ maka tingkat profitabilitas (ROA) akan turun sebesar - 17,1917\%.

$\beta 3=0.008062$ merupakan besarnya kontribusi variabel Loan to Deposit Ratio (LDR) yang mempengaruhi tingkat profitabilitas (ROA). Koefisien regresi (b3) sebesar 0.008062 dengan tanda positif. Jika variabel Loan to Deposit Ratio (LDR) tumbuh $1 \%$ maka 


$\begin{array}{lll}\text { tingkat profitabilitas } & \text { (ROA) } \\ \text { akan meningkat sebesar } & \\ 0,8062 \% & \end{array}$

$\beta 4=\quad-0.083289 \quad$ merupakan besarnya kontribusi variabel Biaya Operasional terhadap Pendapatan Operasional (BOPO) yang mempengaruhi tingkat profitabilitas (ROA). Koefisien regresi (b4) sebesar 0.083289 dengan tanda negatif. Jika variabel Biaya Operasional terhadap Pendapatan Operasional (BOPO) tumbuh $1 \%$ maka tingkat profitabilitas (ROA) akan turun sebesar $8,3289 \%$..

\section{Uji Hipotesis}

Sebagaimana yang telah dilakukan uji signifikan terhadap teknik Common Effect, selanjutnya akan dilakukan uji Hipotesis yakni uji F, T, dan uji Determinan $\left(\mathrm{R}^{2}\right)$.

\section{a. Uji F}

Untuk mengetahui apakah variabel Independent secara simultan (bersama-sama) mempunyai pengaruh terhadap variabel Dependent atau tidak berpengaruh maka digunakan uji F (F-test) yaitu dengan cara membandingkan F-hitung dengan F-tabel dengan

ketentuan sebagai berikut:

Ho : $\beta=0$, berarti tidak ada pengaruh signifikan dari variabel independen terhadap variabel dependen secara simultan (bersama-sama).

Ho : $\beta \neq 0$, berarti ada pengaruh yang signifikan dari variabel independen terhadap variabel dependen secara simultan (bersama-sama).

\section{Tabel 1. Hasil Uji Simultan}

\begin{tabular}{rrr} 
F-hitung & F tabel & P-value \\
\hline $\mathbf{5 2 . 7 4 4 9 8}$ & 2.4675 & 0.0000 \\
\hline
\end{tabular}

Sumber : Data diolah Eviews 5.1, 2011

Berdasarkan hasil analisis regresi data panel pada tabel diatas didapatkan Df1 = 4 dan Df2 = 95, F-tabel sebesar 2,4675. Sedangkan F-hitungnya sebesar 52.74498. Sehingga dari perhitungan di atas dapat diketahui bahwa Ho ditolak dan Ha diterima. Dengan demikian menunjukkan bahwa variabel independent yaitu variabel Capital Adequacy Ration (CAR), Non Performing Loan (NPL), Loan to Deposit Ratio (LDR), dan Biaya Operasional terhadap Pendapatan Operasional (BOPO) mempunyai pengaruh yang signifikan terhadap 
tingkat profitabilitas (ROA) bank

Independent, terhadap variabel umum Go Public di Bursa Efek dependent, maka untuk itu Indonesia (BEI).

digunakan uji t (t-test) dengan cara

b. Uji T

Untuk mengetahui pengaruh masing-masing variabel membandingkan nilai t-hitung dengan t-tabel. Berikut hasil dari regresi data panel Common Effect.

Tabel 2. Perbandingan Antara Nilai $t_{\text {hitung }}$ Dengan $t_{\text {tabel }}$

\begin{tabular}{cccc}
\hline Variabel & $\mathbf{t}_{\text {hitung }}$ & $\mathbf{t}_{\text {tabel }}$ & Keterangan \\
\hline $\mathbf{X}_{\mathbf{1}}$ & -0.782488 & 1,98525 & Tidak Signifikan \\
\hline $\mathbf{X}_{\mathbf{2}}$ & -2.701997 & 1,98525 & Signifikan \\
\hline $\mathbf{X}_{\mathbf{3}}$ & 1.868932 & 1,98525 & Tidak Signifikan \\
\hline $\mathbf{X}_{\mathbf{4}}$ & -10.37266 & 1,98525 & Signifikan
\end{tabular}

Sumber: Data Diolah 2011

Berikut hasil dari pengolahan

signifikan dan positif terhadap

data masing - masing variabel ROA tidak dapat diterima.

bebas terhadap variabel terikat secara parsial, dengan analisis sebagai berikut :

2. Variabel Non Performing Loan

1. Variabel Capital Adequacy (NPL) (X2)

Ratio (CAR) (X1)

Dari hasil uji $t$ variabel CAR menunjukkan nilai $t$ hitung $-0.782488<\mathrm{t}$-tabel 1,98525, dan nilai Probabilitas $0.4359>0,05$. Dapat ditarik kesimpulan bahwa variabel CAR tidak berpengaruh signifikan dan negatif terhadap ROA dengan kata lain Ho diterima dan $\mathrm{Ha}$ ditolak, hipotesis yang menyatakan bahwa rasio CAR berpengaruh

Dari hasil uji t variabel NPL menunjukkan nilai t-hitung $2.701997>$ t-tabel 1,98525, dan nilai Probabilitas $0.0082<0,05$. Dapat ditarik kesimpulan bahwa variabel NPL berpengaruh signifikan dan negatif terhadap ROA dengan kata lain Ho ditolak dan $\mathrm{Ha}$ diterima, hipotesis yang menyatakan bahwa rasio CAR berpengaruh signifikan dan negatif terhadap ROA dapat diterima.

3. Variabel Loan Deposit Ratio (LDR) (X3)

Jurnal Ekonomi Pembangunan Vol.12, No.02 Desember 2014 
Dari hasil analisis menunjukkan bahwa nilai t hitung pada variabel Loan to Deposit Ratio (LDR) sebesar 1.868932 sedangkan $\mathrm{t}$ tabel sebesar 1.98525 , sehingga berdasarkan hasil tersebut dapat digarisbawahi bahwa tidak ada pengaruh yang signifikan variabel Loan to Deposit Ratio (LDR) terhadap tingkat profitabilitas (ROA) dengan asumsi variabel yang lain konstan.

4. Variabel Biaya Operasional terhadap Beban Operasional (X4)

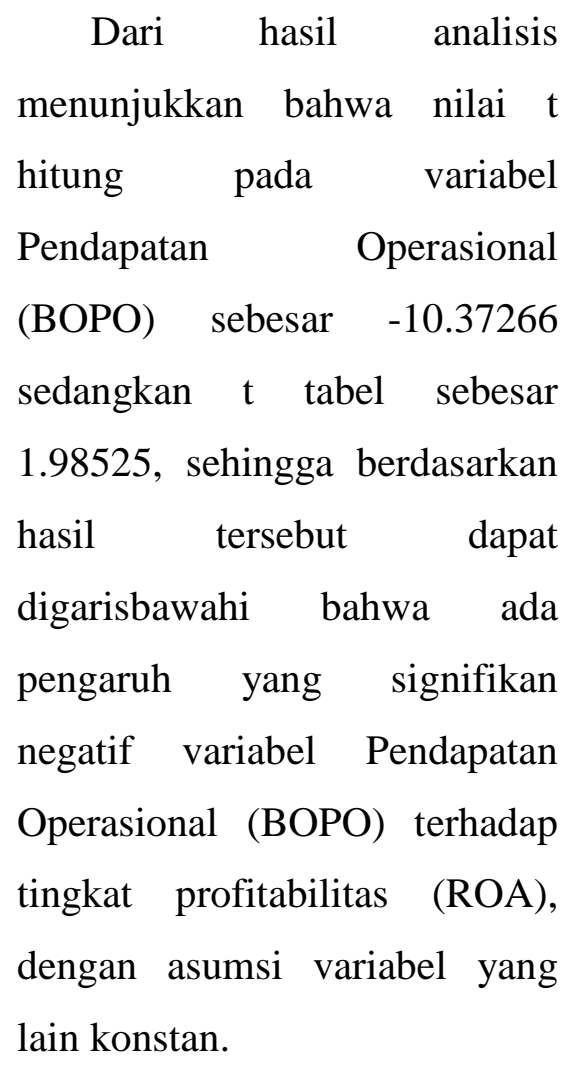

c. Koefesien Determinan $\left(\mathbf{R}^{2}\right)$

Dari hasil perhitungan analisis regresi data panel yang telah dilakukan menunjukkan pengaruh variabel Independent terhadap variabel Dependent adalah cukup besar. Hal tersebut dapat dilihat pada nilai koefisien determinasi (R2) yaitu sebesar 0.689522 yang sudah mendekati 1. Dengan demikian berarti bahwa tingkat profitabilitas (ROA) dapat dijelaskan sekitar $\quad 68,9522 \%$ oleh variable Capital Adequacy Ration (CAR), Non Performing Loan (NPL), Loan to Deposit Ratio (LDR) dan Biaya Operasional terhadap Pendapatan Operasional (BOPO) sedangkan sisanya sekitar 31,0478\% dijelaskan oleh variabel-variabel lain yang tidak termasuk dalam model penelitian ini.

\section{Pengaruh Variabel Capital Adequacy Ration (CAR) Terhadap tingkat profitabilitas (ROA) bank umum Go Public di Bursa Efek Indonesia (BEI) Tidak berpengaruhnya
variabel CAR terhadap ROA
disebabkan karena bank-bank yang}


beroperasi pada periode tersebut perbankan indonesia masih dalam masa penyebuhan (Program restrukturisasi, rekapitalisasi, dan konsolidasi) atau pemulihan akibat dari krisis moneter selama kurun waktu 10 tahun. Dimana pada tahun 1997-2002 tahap awal dari penyebuhan perbankan indonesia dengan melikuidasi 23 bank, rekapitalisasi bank dan melakukan penggabungan 4 bank menjadi bank mandiri. Tahap yang kedua yaitu tahun 2003 sampai dengan 2004 dilakukanya restructuring bank dan pembentukan Arsitektur Perbankan Indonesia (API), dan selanjutnya tahap yang ketiga yaitu periode 2005-2010 dilakukannya merger dan konsolidasi perbankan. Adapun tujuan dari serangkaian program/kebijakan tersbut untuk menciptakan struktur perbankan yang kuat, sehat, dan efisien.

Dengan dikeluarkan nya program atau kebijakan (restrukturisasi, rekapitalisasi, dan konsolidasi) tersebut hal ini mengakibatkan Bank Indonesia mengeluarkan peraturan mengenai besaran Capital Adequacy Ratio (CAR) minimal yang dimiliki oleh bank-bank umum di Indonesia berkisar $8 \%$. Sehingga dengan adanya peraturan yang dikeluarkan Bank Indonesia membuat bankbank selalu berusaha menjaga agar CAR yang dimiliki sesuai dengan ketentuan. Namun bank cenderung menjaga CAR-nya tidak lebih dari $8 \%$, tidak berpegaruhnya CAR terhadap ROA dapat juga terjadi karena pihak bank belum dapat melempar kredit sesuai dengan yang diharapkan atau belum optimal. Dari pengujian yang telah dilakukan bertentangan dengan hasil penelitian oleh M. Shobirin dan Ayu Intan yang menyatakan bahwa variabel CAR berpengaruh terhadap ROA.

\section{B. Pengaruh Variabel Non Performing Loan (NPL) Terhadap Tingkat Profitabilitas (ROA) Bank Umum Go Public di Bursa Efek Indonesia (BEI).}

Adanya pengaruh dengan nilai koefisien senilai -0,171917 (negative) dapat menunjukkan bahwa selama periode penelitian bank belum mampu secara maksimal untuk mengendalikan risiko kredit 
yang terjadi sehingga memiliki dampak negatif dalam proses pencapaian tingkat profitabilitas (ROA). Resiko kredit macet menjadi kendala bagi pihak manajemen dalam proses pengelolaan atau peningkatan pencapaian profibilitas bank. Semakin tinggi kredit macet maka dengan sendirinya upaya pencapaian keuntungan akan terhambat dan hal tersebut salah satu penyebab terjadinya penurunan profitabilitas bank.

Oleh karena itu kenaikan NPL mengakibatkan menurunnya ROA, Selain itu NPL bisa saja terjadi bukan karena debitor tidak sanggup membayar akan tetapi ketatnya Peraturan Bank Indonesia dalam hal penggolongan kredit yang mengakibatkan debitor yang tadinya berada dalam kategori lancar bisa turun menjadi kurang lancar.

C. Pengaruh Variabel Loan to Deposit Ratio (LDR) Terhadap Tingkat Profitabilitas (ROA) Bank Umum Go Public di Bursa Efek Indonesia (BEI)
Hasil analisis menunjukkan bahwa dengan adanya peningkatan deposito berjangka, giro, tabungan, dan lain-lain yang digunakan dalam memenuhi permohonan pinjaman (loan requests) sehingga menentukan tingkat likuiditas yang dimiliki oleh bank. Rasio yang tinggi menunjukkan bahwa bank meminjamkan seluruh dananya atau relatif tidak likuid. Dengan tidak adanya pengaruh yang signifikan tersebut dapat menunjukkan bahwa selama periode penelitian bank tidak mampu secara maksimal dalam menghimpun dana kredit yang disalurkan oleh bank tidak banyak memberikan kontribusi laba, kurangnya mengoptimalkan dana pihak ketiga, sehingga tidak memiliki pengaruh dalam peningkatan profitabilitas (ROA).

\section{Pengaruh Pendapatan}

Operasional

(BOPO)

Terhadap Tingkat

Profitabilitas (ROA) Bank

Umum Go Public di Bursa

Efek Indonesia (BEI) 
Adanya pengaruh negatif menunjukkan bahwa dengan meningkatnya BOPO pada perusahaan perbankan menandakan perusahaan lebih banyak mengeluarkan biaya operasional dalam menghasilkan laba. Kondisi ini juga menandakan bahwa perusahaan yang menghasilkan laba besar tidak efisien dalam melakukan operasionalnya sehingga BOPO berpengaruh negatif terhadap ROA. Hal ini berarti tingkat efisiensi bank dalam menjalankan operasinya, berpengaruh terhadap tingkat pendapatan yang dihasilkan oleh bank tersebut. Jika kegiatan operasional dilakukan dengan efisien dalam hal ini nilai rasio BOPO rendah maka pendapatan yang dihasilkan bank tersebut akan naik.

\section{PENUTUP}

Berdasarkan hasil analisis regresi data panel yang telah dilakukan pada bab-bab sebelumnya, maka dapat ditarik kesimpulan sebagai berikut:

Hasil Uji F menunjukkan Varibael bebas Rasio CAR, NPL,
LDR, BOPO, berpengaruh simultan atau serentak terhadap variabel ROA, dapat dilihat dari nilai uji F-hitung $(191,77)>$ Ftabel $(2,467)$.

Hasil Uji-t untuk Variabel CAR tidak berpengaruh signifikan dan negatif terhadap ROA, Hal ini berarti peran kecukupan modal bank dalam menajalakan usaha pokoknya, tidak mempengaruhi profitabilitas

Hasil Uji-t untuk Variabel NPL berpengaruh dan negatif terhadap ROA, Jadi hipotesis yang menyatakan bahwa rasio NPL berpengaruh signifikan dan negatif terhadap ROA dapat diterima.

Hasil Uji-t untuk Variabel LDR tidak berpengaruh signifikan dan positif terhadap ROA, sehingga dapat digarisbawahi bahwa tidak ada pengaruh yang signifikan variabel LDR terhadap tingkat ROA.

Hasil Uji-t untuk Variabel BOPO berpengaruh negatif dan signifikan terhadap ROA. sehingga dapat disimpulkan bahwa kinerja keuangan suatu perbankan semakin meningkat atau semakin membaik. Sedangkan hasil uji 
koefisien

determinasi

menunjukkan pengaruh variabel

Independent terhadap variabel

Dependent adalah cukup besar,

\section{DAFTAR PUSTAKA}

Dahlan Siamat. 2005. Manajemen Lembaga Keuangan Kebijakan Moneter dan Perbankan Edisi Kelima. Jakarta : Fakultas Ekonomi Universitas Indonesia.

Drs. Syafaruddin Alwi. 1991. Alatalat Analisis Dalam Pembelajaran Edisi Revisi Yogyakarta : Andi Offset.

Eugene F Brigham \& Joel F. Houston. 2001. Manajemen Keuangan Edisi Kedelapan. Jakarta: Penerbit Erlangga.

Fitriani Prastiyaningtyas. 2010. Faktor-faktor yang mempengaruhi

Profitabilitas perbankan (Studi Pada Bank Umum Go Public Yang Listed di Bursa Efek Indonesia Tahun 20052008).Fakultas Ekonomi. Universitas Diponegoro Semarang.

Gill James O \& Moira Chatton. 2003. Memahami
Laporan Keuangan. Jakarta: Penerbit PPM.

Lepi T. Tarmidi. 2007. Krisis Moneter Indonesia : Sebab, Dampak, Peran, IMF dan Saran.

Lukman Dendawijaya. 2004. Lima Tahun Penyehatan Nasional. Bogor Selatan : Ghalia Indo.

Mamduh M Hanafi. 2003. Analsis Laporan Keuangan. Yogyakarta : Unit Penerbit dan Percetakan AMP-YKPN.

Mudrajad Kuncoro Suharjono. 2002. Manajemen Perbankan Teori dan Aplikasi Edisi Pertama. Yogyakarta : BPFEYogyakarta.

Ponttie Prasnanugraha P. 2007. Analisis Pengaruh Rasiorasio Keuangan Terhadap Kinerja Bank Ummum di Indonesia. Tesis. Universitas Diponegoro.

Sawidji Widoatmodjo. 2004. Jurus Jitu Go Public. Jakarta : PT. Alex Media Komputindo.

Sri Wahyuni Kasbal. 2011. Analisis Pengaruh CAR, NPL, LDR, NIM, BOPO Terhadap Profitabilitas 
pada Perusahaan

Perbankan di Indonesia.

Fakultas Ekonomi.

Universitas Hasanudin.

Veithzal Rivai, Dkk. 2007. Bank and Financial Institution Management. Jakarta : PT.Rajagrafindo Persada. . 2006. Credit Management Handbook
Teori, Konsep, Prosedur, dan Aplikasi. Jakarta : PT.RajaGrafindo Persada

Yusti Agistiara. 2010. Analisis Faktor-Faktor Yang Mempengaruhi Profitabilitas Perbankan Go Publik (Studi Kasus Bank Go Public Tahun 2005-2009). Fakultas Ekonomi. Universitas Diponegoro Semarang. 